\title{
Reconsidering the 'Neolithic' at Manim rock shelter, Wurup Valley, Papua New Guinea
}

\author{
Tim Denham
}

\section{Is the 'Neolithic' relevant to the highlands of Papua New Guinea?}

What needs to be pointed out at this stage is that there was no point at which a homogenous Neolithic 'package' of economic practice and material culture ever existed. (Thomas 1999:14)

... in practice the evidence which is available to us relates to a more complex, messy and fragmented series of developments, and that any attempt to define a particular set of attributes as constituting the Neolithic will be arbitrary in the extreme. (Thomas 1999:13)

The term 'Neolithic' was proposed by Lubbock (1865) as a formal category to differentiate the Palaeolithic_-namely, old flaked stone technologies-from new ground and polished stone technologies. Subsequently, a range of alternative meanings of the Neolithic have emerged (Trigger 2003). Childe (1925) shifted the emphasis from evolutionary perspectives on stone tool technology onto sets of culture-historic traits, albeit with temporal and geographical variation. During the 20th century, the concept of the Neolithic broadened to encompass agriculture (associated with domesticated plants and animals), sedentism, pottery and mortuary practices, as well as stone tool technology. Subsequently, Hodder (1990) drew attention to the social and symbolic aspects of the Neolithic, while Thomas (1999) considered the Neolithic to be more a way of 'Being'. Today, in both academic and public discourse, the Neolithic has become a signifier of social complexity, dynamism and progression (David and Denham 2006; Florin and Carah 2018).

It remains to be seen how relevant the concept of the Neolithic is outside Eurasia, the region of its original development and application. Does the concept reflect something fundamental about long-term social history, or is it chronologically and geographically specific? Indeed, does the concept have too much inherited baggage, which would make its relevance to the highlands of New Guinea problematic?

Here, the lithic assemblage at Manim, a rock shelter in the highlands of Papua New Guinea, is re-evaluated in terms of Lubbock's initial usage, namely in terms of the advent of ground stone tool technology. Subsequently, broader conceptions of the Neolithic, namely those that draw on a suite of cultural traits, are evaluated in terms of the multidisciplinary record for the highlands. 


\section{Taking another look at Manim}

Ground stone axe-adzes were 'an important component of most tool kits in the Western Highlands' of Papua New Guinea by c. 7000-6000 cal BP and would greatly have increased the efficiency of forest clearance (Christensen 1975:33). Christensen based his interpretation on the results of his excavations at Manim rock shelter in the Wurup Valley, together with Bulmer's excavations at Kiowa and Yuku (Bulmer and Bulmer 1964:66). Tools with edge grinding dated to the early Holocene at Kafiavana (White 1972:195) and Kosipe (White et al. 1970:162), with less specific reports of ground artefacts dating to the Pleistocene at Kosipe (White et al. 1970:165) and Yuku (Bulmer 1975:31; cf. Bulmer 1977a:57). The only definite edge ground tool from the Pleistocene was an axe with butt modification from the earliest occupation at Nombe (Golson 2001:196). Christensen (1975:32; after White 1967) noted that the Kafiavana collection provided evidence of early Holocene grinding on the faces, sides and cutting edge. The marked increase in the frequency of ground stone tools from c. 7000-6000 cal BP loosely correlated with a decrease in the variety of other stone tools (Bulmer 1975:44).

Ground stone axe-adzes have become embroiled in debates concerning archaeological signatures of the 'Neolithic' (Denham 2003, 2006) and early agriculture in the highlands (Bulmer 1966, 1975, 1977a, 1977b, 1991, 2005; Gaffney et al. 2015a; Golson 2005). Although the ground stone axe-adzes at Manim are not the earliest in the highlands (Mountain 1991; White 1972; see reviews in Bulmer 2005 and Golson 2005), they are highly significant because of the site's proximity to wetlands preserving archaeological evidence of early agriculture on the floor of the Upper Wahgi Valley, including Kuk Swamp (Denham and Haberle 2008). Manim is located in the Wurup Valley, a tributary of the Upper Wahgi Valley, less than $20 \mathrm{~km}$ away from Kuk (Figure 6.1). The potential correlations between the adoption of ground stone axe-adzes at Manim, forest clearance on the valley floor, and the agricultural chronology at Kuk are significant for developing a regional understanding of human-environment interactions during the early to mid-Holocene (Denham and Haberle 2008), as well as of the emergence of agrarian societies in the Upper Wahgi Valley.

Despite the centrality of Christensen's excavations at Manim to debates concerning the antiquity and prevalence of ground stone tool technology in the highlands (Burton 1984:227-228; Christensen 1975; Golson 2005:469; Mangi 1984), there are problems with the previous radiocarbon dating. Previous conventional radiocarbon dates were derived from different test units to those containing key lithic materials and they were obtained on relatively large samples of wood charcoal. Here, a new accelerator mass spectrometry (AMS) dating program relies, where possible, on short-lived macrobotanical remains, primarily Pandanus sp. nut and kernel fragments, collected from the same excavation quadrant within one test unit (Test Unit I), which contained several significant stone artefacts. The new dating program has greater precision and a higher degree of chronostratigraphic control in terms of the association between dated materials and ground stone artefacts. 


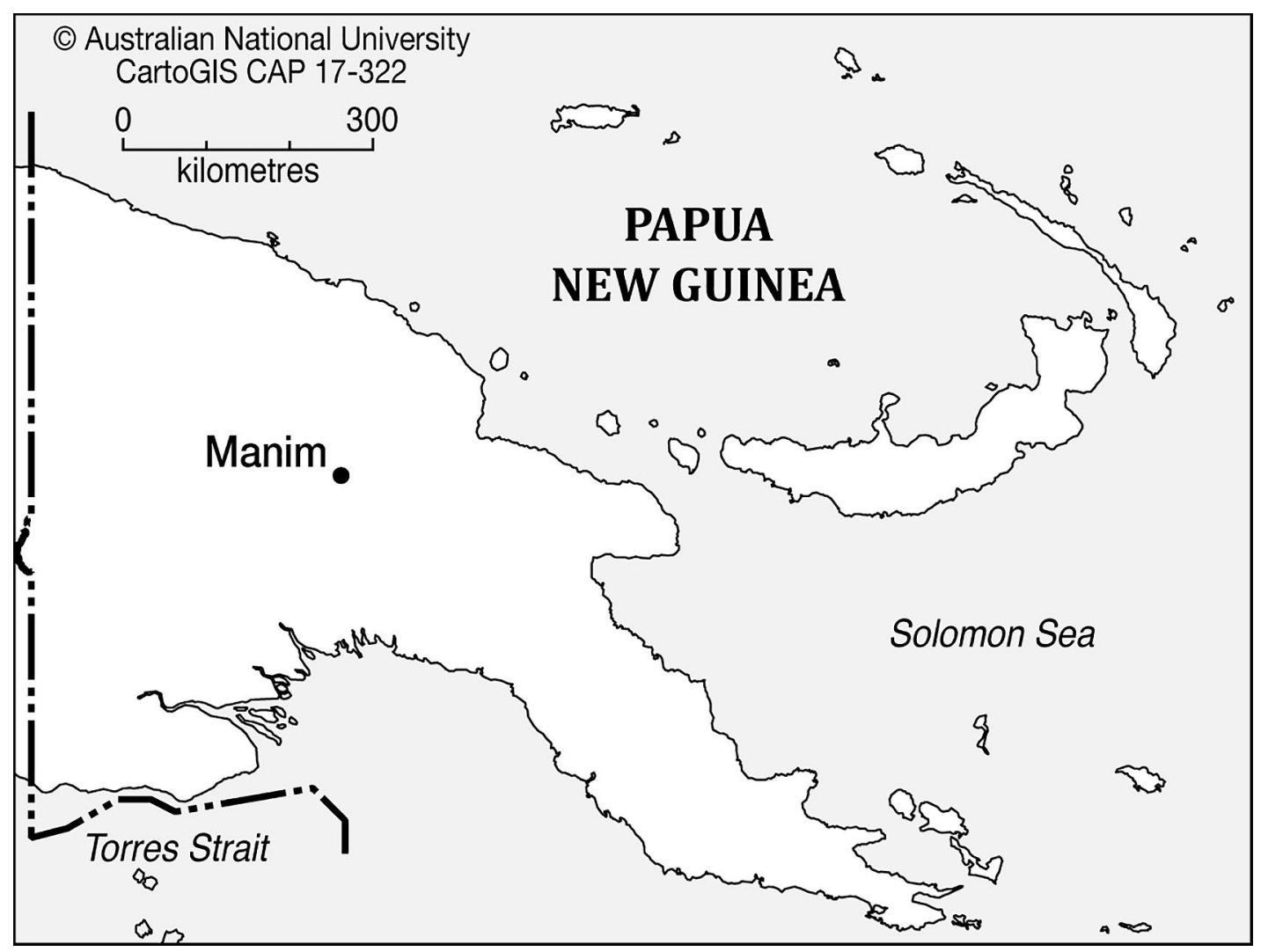

Figure 6.1. Location map of Manim rock shelter in Papua New Guinea.

Source: Tim Denham.

\section{The Manim excavations}

In the early 1970s, Ole Christensen conducted extensive archaeological and ethnobotanical investigations in the Wurup Valley near Mount Hagen, Western Highlands Province, Papua New Guinea. Tragically, he died in a car accident before completing his doctoral studies. In 1973 Christensen undertook excavations at four rock shelters along an altitudinal cline on the wall of the Wurup Valley: Manim (1770 m), Kamapuk (2050 m), Etpiti (2200 m) and Tugeri (2450 m). Only limited analyses of the archaeobotanical, archaeozoological and lithic assemblages from his archaeological excavations have occurred (Aplin 1981; Donoghue 1988; Mangi 1984) or been published (Christensen 1975; Donoghue 1989; Sutton et al. 2009).

At Manim, extensive excavations were undertaken within the rock shelter, exposing relatively deep stratigraphy (Figure 6.2; Table 6.1). Excavations were ordinarily conducted in arbitrary $10 \mathrm{~cm}$ levels within stratigraphic layers. Manim yielded dense lithic (Mangi 1984) and archaeobotanical (Donoghue 1988) assemblages associated with occupation during the early to mid-Holocene (Christensen 1975). These cultural deposits occurred within Layer V, which extended to depths of 'circa $250 \mathrm{~cm}$ below the surface at the back of the shelter to circa $340 \mathrm{~cm}$ below the surface outside of the dripline' (Christensen 1975:30). 

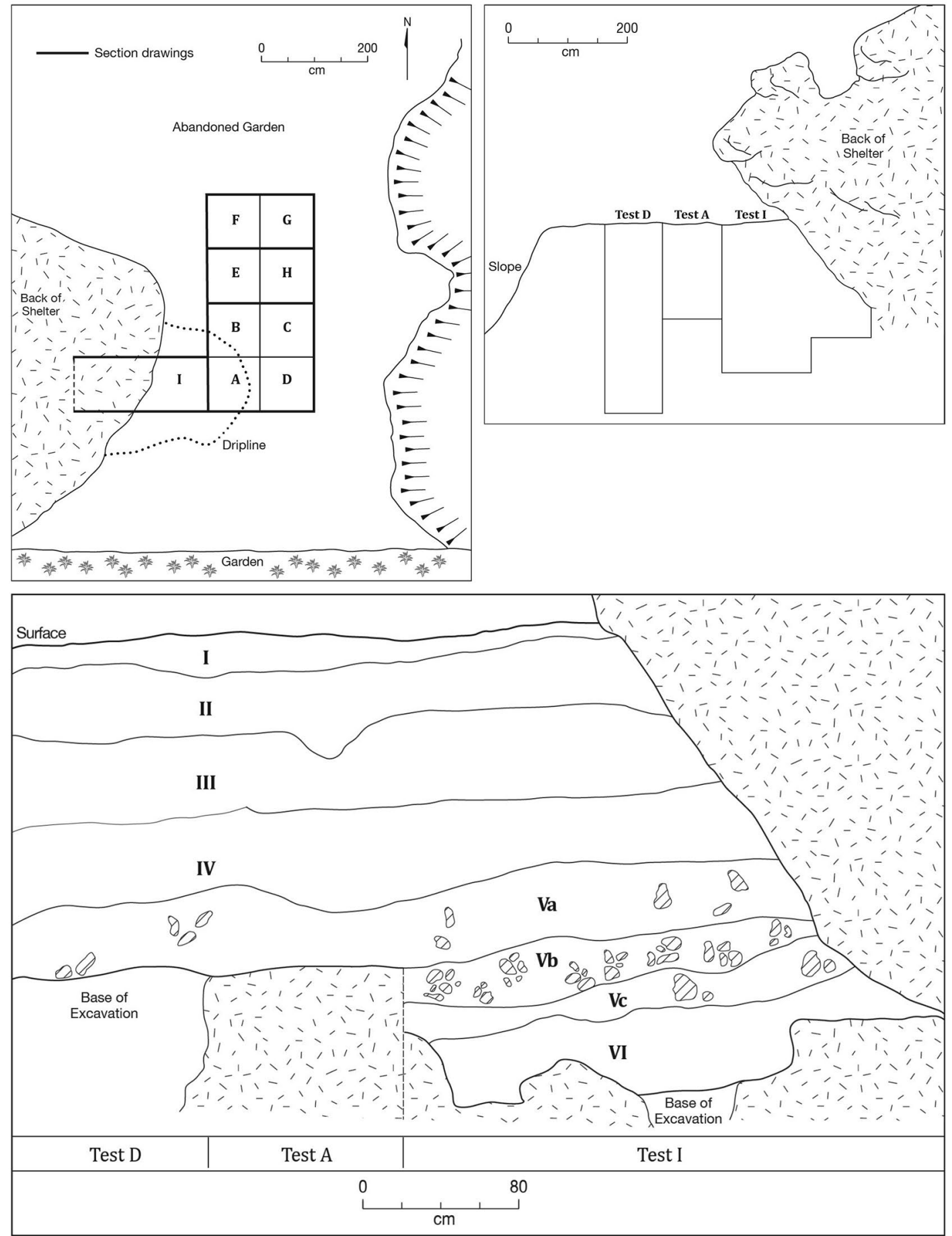

Figure 6.2. Site plan of excavations at Manim rock shelter (top left), with east-west cross-sectional view (top right), and section of south wall of Test Units D, A and I (bottom).

Source: Redrafted from Christensen field notes in Garrett (1976). 
Table 6.1. Stratigraphy in Manim rock shelter (based on Christensen 1975:30, Garrett 1976:32-34 and Mangi 1984:15-17).

\begin{tabular}{|c|c|c|}
\hline Layer & Levels & Description \\
\hline I & $1-3$ & $\begin{array}{l}\text { Root mat (upper c. } 10 \mathrm{~cm} \text { ) formed on a clay-rich sediment containing charcoal, sparse cultural } \\
\text { material and occasional lenses of sand and clay. The clay lenses potentially delineate shallow } \\
\text { hearths and are associated with fire-cracked rocks. }\end{array}$ \\
\hline$\|$ & $4-7$ & $\begin{array}{l}\text { Dark organic sand containing charcoal, clusters of fire-cracked rock, stone flakes and fragments } \\
\text { of cooking stones throughout. }\end{array}$ \\
\hline III & $8-13$ & Bands of sands, which vary in colour and texture, and contain sparse cultural materials. \\
\hline IV & $14-17$ & $\begin{array}{l}\text { The upper portion comprises a dark grey clay containing abundant charcoal and other cultural } \\
\text { material, such as fire-cracked rock and stone flakes. The lower portion is a yellowish sand } \\
\text { containing sparse cultural materials. }\end{array}$ \\
\hline Va & $18-21$ & \multirow{3}{*}{$\begin{array}{l}\text { Black organic layer containing densely packed cultural materials, primarily charcoal, fire-crackec } \\
\text { rock and lithic artefacts. Towards the base, the sediment is browner, less organic and more } \\
\text { clay-rich, and contains fewer cultural materials. }\end{array}$} \\
\hline $\mathrm{Vb}$ & $22-24$ & \\
\hline Vc & $25-26$ & \\
\hline $\mathrm{VI}$ & $27-29$ & White sand between rocks. \\
\hline
\end{tabular}

Levels for Layers are provided for Unit I. Associated depths can be inferred from Figure 6.2.

Source: Author's research.

\section{The lithic assemblage at Manim}

An independent re-evaluation of the stone assemblage at Manim is not possible, given the extensive damage and losses to the lithic collection during the destruction of the Weston archaeological store as a result of the Canberra fires of 2003. Consequently, any evaluation is constrained by previously published and unpublished reports (Burton 1984; Christensen 1975; Garrett 1976; Mangi 1984). Although these documents provide ample detail, they contain inconsistencies and do not enable a complete reconstruction of the provenance for all ground stone artefacts.

There are differences in the reporting of the ground stone axe-adzes and related artefact classes at Manim. Mangi $(1984: 55,90)$ provides a working definition for a ground axe-adze as 'characterised by a ground edge at one end "resembling those hafted and used as axes and adzes in recent times and usually exhibit signs of polishing"' (cf. Bulmer 1966:66; White 1972:6). Although it is not possible to define these artefacts as axes or adzes without knowledge of how they were hafted, Mangi (1984:90) referred to them as 'axes' for convenience. Burton (1984) also referred to them as axes, based on the presumption that except for one small wood-working adze, only axes were manufactured in quarries in the Wahgi Valley vicinity; although he notes that this ethnographic inference may not extend to archaeological samples (John Burton, pers. comm. 2016). Axe-adzes at Manim were reported as lenticular (Mangi 1984) or ovoid (Burton 1984) in cross-section.

As well as five complete ground stone axe-adzes, there were four broken axe-adzes, three 'roughouts' or blanks, and twenty-three 'axe flakes' (Mangi 1984:105-106). 'Axe roughouts' were extensively flaked on all sides and conformed in shape to an axe-adze, but lacked any grinding or polishing; namely, they may potentially be at an earlier stage of the manufacturing process prior to grinding and polishing. 'Axe flakes' were differentiated from other flakes based on the presence of striations along the polished surface (Mangi 1984:90); they were derived from breakage or reworking of ground axe-adzes.

All except one axe flake were collected from Layer $\mathrm{V}$, the main period of cultural deposition at Manim; the exception derived from overlying Layer IV. Mangi (1984) undertook a tripartite subdivision of Layer $\mathrm{V}(\mathrm{Va}, \mathrm{Vb}$ and $\mathrm{Vc})$. The vast majority of stone artefacts, flakes and debitage were derived from Layers $\mathrm{Va}$ and $\mathrm{Vb}$ : Layer $\mathrm{Va}$ yielded all whole and broken axe-adzes, two roughouts and ten axe flakes; and, Layer $\mathrm{Vb}$ yielded one roughout and twelve axe flakes. 


\section{Previous radiocarbon dating}

In the preliminary report of the excavations, there is some confusion over the provenance and antiquity of the earliest ground axe-adzes at Manim (Table 6.2). Christensen states:

ANU-1372 (3580 \pm 80$)$ comes from the top of the stratigraphic unit within which ground stone axe/adzes first appear. ANU$1373(5860 \pm 130)$ is from the lowest spit within which axe/adzes (lenticular) appear. (Christensen 1975:31)

Subsequently in the same report, the first appearance of ground stone axe-adzes is stated as being in Level ' $G 19$, dated to $5860 \pm 130 \mathrm{BP}$ ' (Christensen 1975:32), presumably, Level 19 in Test Unit G. There is an inconsistency because ANU-1373 is listed as being from Level 21 (Christensen 1975:Table 1) and not Level 19 as stated in the text.

In his analysis, Mangi (1984:106) states that all the earliest complete ground and polished axe-adzes come from Layer Va in Test Unit I, although specifics are only given for two from Level 21 and one from Level 20 (1984:Figures VIIa-c). Furthermore, a consideration of Christensen's field notes (transcribed in Mangi 1984:Appendix I) confirms the interpretation that the oldest axe-adzes derive from Level 21 in Test Unit I, rather than Level 19, but that they come from the top of this excavation level and could be readily assigned to Level 20 .

Mangi's interpretation is corroborated by Burton (1984:227-228) who states that the earliest ground stone axe-adzes come from Level 21. Burton (1984:Figure 10.14) depicts the oldest finds, both derived from Level 21 in Test Unit I and describes them as 'two miniature axes of ovoid section made from local stone' (Figure 6.3; Burton 1984:227). Burton (1984:227) also discusses a small cutting edge fragment from a ground stone axe that is likely derived from the Tuman quarries; the provenance for this fragment (Artefact 327), which is from a provenance below ANU-1372 $(3580 \pm 80 \mathrm{BP})$, is given as Quadrant 2, Level 19 in Test Unit I (Burton 1984:Table 10.7).

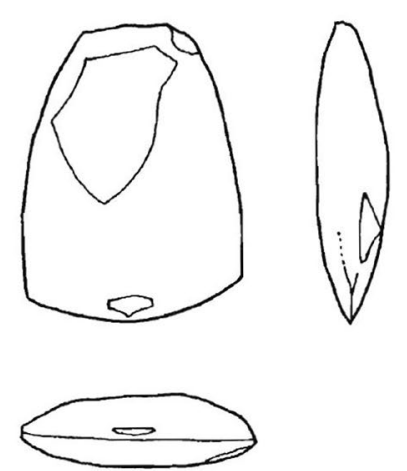

I $6280 \mathrm{~A}$
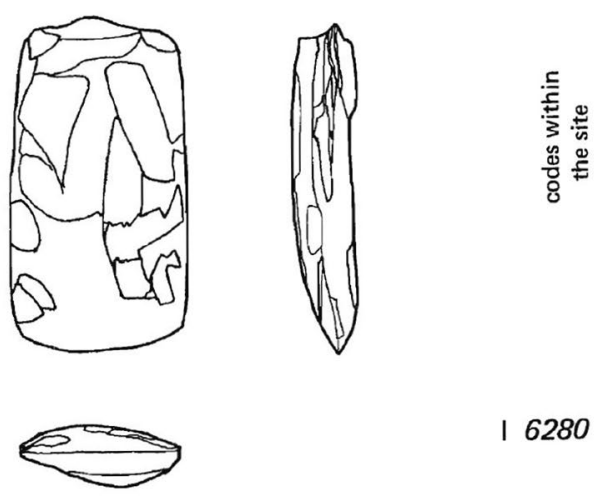

I 6280

Figure 6.3. The oldest ground axe-adzes from Level 21, Quadrant 6, Test Unit I at Manim rock shelter (Burton 1984:Figure 10.14, reproduced with permission): top, artefact $6280 \mathrm{~A}$; bottom, artefact 6280.

Source: Burton 1984:Figure 10.14.

A review of the current literature confirms that the earliest Tuman quarry axes and the earliest ground axes at Manim derive from Levels 19 and 21 (and, conservatively from Level 20), respectively, in Test Unit I. Based on previously published data, the earliest Tuman quarry axes at Manim predate c. 4090-3690 cal BP and the earliest ground axe-adzes date to c. 7010-6400 cal BP. However, there is uncertainty over the precise antiquity of these artefacts because the radiocarbon dates that are used to date them are largely derived from Test Unit $\mathrm{G}$, which was the furthest excavated from Test Unit I that contained several of the most significant ground stone artefacts. 
Table 6.2. Previously reported conventional radiocarbon dates on wood charcoal for Manim.

\begin{tabular}{|c|c|c|c|c|c|c|c|}
\hline Laboratory code & $\begin{array}{l}\text { Radiocarbon } \\
\text { age (BP) }\end{array}$ & Sample type ${ }^{1}$ & $\begin{array}{l}\text { Radiocarbon } \\
\text { date (cal BP) }\end{array}$ & \% (2 sigma) & Test Unit & Level/Quad & Layer $^{2}$ \\
\hline ANU-1368 & $410 \pm 70$ & Wood charcoal & 538-308 & 95.4 & $\mathrm{~F}$ & 3 & II \\
\hline ANU-1369 & $270 \pm 80$ & Wood charcoal & $\begin{array}{l}504-254 \\
225-136 \\
115-73 \\
34-m o d e r n \\
\end{array}$ & $\begin{array}{l}68.9 \\
17.2 \\
2.9 \\
6.3 \\
\end{array}$ & G & 6 & II \\
\hline ANU-1370 & $2380 \pm 110$ & Wood charcoal & $\begin{array}{l}2741-2296 \\
2268-2156\end{array}$ & $\begin{array}{l}85.3 \\
10.1\end{array}$ & $E$ & 11 & IV \\
\hline ANU-1371 & $2300 \pm 90$ & Wood charcoal & $\begin{array}{l}2703-2630 \\
2619-2559 \\
2544-2110 \\
2080-2068\end{array}$ & $\begin{array}{l}5.8 \\
3.5 \\
85.6 \\
0.5\end{array}$ & $E$ & 12 & IV \\
\hline ANU-1372 & $3580 \pm 80$ & Wood charcoal & $\begin{array}{l}4140-4130 \\
4091-3686 \\
3664-3645 \\
\end{array}$ & $\begin{array}{l}0.6 \\
93.6 \\
1.3 \\
\end{array}$ & H & 16 & Va \\
\hline ANU-1373 & $5860 \pm 130$ & Wood charcoal & $\begin{array}{l}7138-7134 \\
7006-6396 \\
6367-6351\end{array}$ & $\begin{array}{l}0.1 \\
94.8 \\
0.5 \\
\end{array}$ & G & 21 & Va \\
\hline ANU-1375 & $9670 \pm 220$ & Wood charcoal & 11 804-10 401 & 95.4 & 1 & 26 & $\mathrm{Vb}$ \\
\hline ANU-1467³ & $9260 \pm 120$ & Wood charcoal & $10755-10200$ & 95.4 & G & 32 & $V c$ \\
\hline ANU-1468 3 & $9870 \pm 610$ & Wood charcoal & $\begin{array}{l}13 \text { 010-9886 } \\
9847-9817\end{array}$ & $\begin{array}{l}95.2 \\
0.2\end{array}$ & G & 33 & Vc \\
\hline ANU-13764 & $5570 \pm 410$ & Wood charcoal & $\begin{array}{l}7414-7391 \\
7372-7357 \\
7332-5583\end{array}$ & $\begin{array}{l}0.3 \\
0.2 \\
94.9\end{array}$ & $\mathrm{H}$ & 34 & Vc \\
\hline
\end{tabular}

Most dates from Christensen (1975:30-31), except ANU-1467 and ANU-1468 from Mangi (1984:23-25). However, the radiocarbon ages for these latter two dates were incorrectly reported in Mangi (1984). Radiocarbon calibrations calculated using IntCal13 (Reimer et al. 2013) and 0xCal v4.2.4 (Bronk Ramsey 2009).

Notes:

1. Sample types vary on the original submission forms and radiocarbon age reports from The Australian National University (ANU) laboratory. They include carbonised wood, charcoal, charred wood and wood; however, it has been inferred that all samples were wood charcoal.

2. Layer designations are derived from Christensen's field notes and layer-level designations as reported in Mangi (1984:Appendix I). Further, and following Mangi (1984), Layer V has been subdivided into three sub-units-Layers Va, $\mathrm{Vb}$ and $\mathrm{V} c$-given that these are relevant for stone artefact distributions within the profile. Further, ANU-1467, ANU-1468 and ANU-1376 are all derived from the basal levels of Layer Vc in Test Units $G$ and I.

3. The radiocarbon ages for ANU-1467 and ANU-1468 were reversed in Mangi (1984:23-25). The original radiocarbon submission forms and original radiocarbon age reports were consulted for the present study.

4. ANU-1376 is anomalous. Mangi (1984:25) reported from the radiocarbon dating report that it was of small size, being 10 per cent of the ANU laboratory requirement for a conventional radiocarbon date at the time.

Source: Author's research.

\section{New AMS dating strategy}

A new AMS dating strategy has been devised to provide greater radiometric precision and a higher degree of association between dated materials and ground stone axe-adzes for Test Unit I. Foremost, it was decided to focus on short-lived plant products, where possible, for radiocarbon dating, primarily Pandanus kernel and nut fragments (pidgin: karuka; highland Pandanus spp.). These materials do not have an in-built 'old-wood effect', because they are produced annually. Individual Pandanus fragments were subject to AMS dating, which can provide higher precision for small organic remains than possible using conventional methods. 
The lowest stone axes were collected from Quadrant 6 within Levels 20 and 21 of Layer V (Mangi's Layer Va). Due to the high density of cultural materials present, Christensen divided each arbitrary spit or level into six quadrants in Test Units E, F, G, H and I when excavating above, through and below Layer V. Here, the intention is to date materials from the same quadrant from which significant stone artefacts were recovered within Test Unit I in order to provide a higher degree of association than relying on inter-test unit and cross-site correlations.

A series of macrobotanical samples were selected for AMS dating through the whole stratigraphic column within Test Unit I to determine the reliability of the original dating program. Particular focus was placed upon the internal chronostratigraphic integrity of the main cultural deposit (Layer V, equivalent to Levels 18-26), as well as its relationship to overlying (Layer IV, Level 17) and underlying (Layer VI, Level 27) units within Quadrant 6. A series of near-continuous AMS dates through these levels was designed to derive the most accurate dates for the earliest stone axe-adzes and associated artefact classes. Individual pieces of archaeobotanical materials were selected for dating from sieved materials (as was the case with the original dating program); none had been sampled in situ from the walls or floor of the excavation.

The results of the new AMS dating program within Test Unit I are in relatively good chronostratigraphic order (Table 6.3). As noted for other cave and rock shelter sites (see Denham and Mountain 2016), there is some clustering of dates within stratigraphic units, which may be suggestive of intermixing within defined periods of occupation, as well as result from the different apparent ages of annually grown Pandanus kernels and nuts with respect to wood charcoal, which may have an in-built 'old-wood effect' of up to several hundred years.

The uppermost four AMS dates (Wk-22063-65 and Wk-22358) predominantly date to the last 800 years. They are not in strict chronostratigraphic order, as Wk-22358 is older than its stratigraphic position would suggest, perhaps indicating an in-built 'old-wood effect'; namely, the wood charcoal was already several hundred years old at the time it was burned, whereas Wk-22065 was younger. However, an inversion in the original wood charcoal dates between Levels 3 (ANU-1368) and 6 (ANU-1369) (Table 6.2; Christensen 1975) suggests that it is more likely that the upper six levels of the site are somewhat intermixed, probably as a result of scuffage, trampling and incidental digging during periodic visitation.

The remaining AMS dates down the profile are in relatively good stratigraphic order. The slightly younger date for Pandanus in Level 19 (Wk-22071) when compared to those for gymnosperm from Levels 17 and 18 (Wk-22069 and Wk-22070) may represent a slight 'old-wood effect' in the gymnosperm samples when compared to Pandanus, or indicate limited intermixing between Levels 17-19. The other anomaly is a wildly aberrant, ancient date on Pandanus in Level 25 (Wk-22076), which is suggestive of residual material being redeposited in a younger context.

The new AMS dates compare relatively favourably with the original conventional dates. There are some minor discrepancies between dates for the same numerical levels, but these are anticipated because the new and old samples were derived from different test units. Namely Level 21 in Test Unit I may not represent precisely the same period of cultural deposition as Level 21 in Test Unit G. Therefore some variation in dates for levels within major cultural strata would be anticipated across the site, especially given variations in the depth of cultural materials across the site, even if the dates for the major cultural strata are broadly consistent. 
Table 6.3. New AMS dates for Manim. Radiocarbon calibrations calculated using IntCal13 (Reimer et al. 2013) and 0xCal v4.2.4 (Bronk Ramsey 2009).

\begin{tabular}{|c|c|c|c|c|c|c|c|}
\hline Laboratory code & $\begin{array}{l}\text { Radiocarbon } \\
\text { age (BP) }\end{array}$ & Sample type & $\begin{array}{l}\text { Radiocarbon } \\
\text { date (cal BP) }\end{array}$ & $\%$ (2 sigma) & Test Unit & Level/Quad & Layer \\
\hline Wk-22063 & $108 \pm 30$ & Charcoal & $\begin{array}{l}270-211 \\
205-187 \\
148-12 \\
\end{array}$ & \begin{tabular}{|l|}
27.1 \\
2.4 \\
65.9 \\
\end{tabular} & 1 & 2 & I \\
\hline Wk-22064 & $279 \pm 30$ & Charcoal & $\begin{array}{l}437-350 \\
334-284 \\
167-155 \\
\end{array}$ & \begin{tabular}{|l|}
53.7 \\
39.3 \\
2.5 \\
\end{tabular} & I & 4 & II \\
\hline Wk-22358 & $857 \pm 30$ & Charcoal & $\begin{array}{l}900-867 \\
824-815 \\
800-693\end{array}$ & \begin{tabular}{|l|}
8.3 \\
1.4 \\
85.7 \\
\end{tabular} & 1 & 5 & II \\
\hline Wk-22065 & $655 \pm 32$ & Charcoal & $\begin{array}{l}673-625 \\
607-556 \\
\end{array}$ & $\begin{array}{l}45.6 \\
49.8 \\
\end{array}$ & 1 & 6 & II \\
\hline Wk-22067 & $2243 \pm 30$ & Charcoal & $\begin{array}{l}2340-2295 \\
2270-2155\end{array}$ & $\begin{array}{l}26.6 \\
68.8 \\
\end{array}$ & 1 & 10 & III \\
\hline Wk-22068 & $2634 \pm 30$ & Charcoal & 2791-2727 & 95.4 & 1 & 12 & III \\
\hline Wk-22069 & $3106 \pm 30$ & Gymnosperm & $3384-3235$ & 95.4 & 1 & $17 / 6$ & IV \\
\hline Wk-22070 & $3279 \pm 30$ & Gymnosperm & $3578-3446$ & 95.4 & 1 & $18 / 6$ & Va \\
\hline Wk-22071 & $3086 \pm 30$ & Pandanus sp. & $3371-3220$ & 95.4 & 1 & $19 / 6$ & Va \\
\hline Wk-22072 & $5712 \pm 30$ & Pandanus sp. & $\begin{array}{l}6626-6587 \\
6568-6411 \\
\end{array}$ & \begin{tabular}{|l|}
5.3 \\
90.1 \\
\end{tabular} & 1 & $20 / 6$ & Va \\
\hline Wk-22073 & $6437 \pm 30$ & Pandanus sp. & 7426-7293 & 95.4 & 1 & $21 / 6$ & Va \\
\hline Wk-22074 & $7430 \pm 32$ & Pandanus sp. & $8335-8184$ & 95.4 & 1 & $22 / 6$ & $\mathrm{Vb}$ \\
\hline Wk-22075 & $8229 \pm 30$ & Pandanus sp. & $\begin{array}{l}9300-9086 \\
9051-9034\end{array}$ & $\begin{array}{l}93.7 \\
1.7 \\
\end{array}$ & I & $24 / 6$ & $\mathrm{Vb}$ \\
\hline Wk-22076 & $18686 \pm 78$ & Pandanus sp. & $\begin{array}{l}22770- \\
22375\end{array}$ & 95.4 & 1 & $25 / 6$ & Vc \\
\hline Wk-22077 & $9062 \pm 35$ & Pandanus sp. & $\begin{array}{l}10253^{-} \\
10187\end{array}$ & 95.4 & 1 & $27 / 1$ & $\mathrm{VI}$ \\
\hline
\end{tabular}

Layer and Level correlations for Test Unit I are given in Table 6.1.

Source: Author's research.

\section{The antiquity of ground stone technology at Manim}

The new AMS dates provide a robust framework for interpreting the antiquity of the earliest ground stone axe-adzes at Manim. Technically, the two oldest axe-adzes at the site derive from Quadrant 6, Level 21 in Test Unit I, which yielded a date of 7430-7290 cal BP (Wk-22073). A third axe-adze was recovered from Quadrant 6, Level 20 in Test Unit I, which yielded a date of 6630-6410 cal BP (Wk-22072). Based on a consideration of Christensen's recommendation in his field notes, the stone axe-adzes can be conservatively dated to 6630-6410 cal BP, although based on a more literal reading of association within discrete quadrants and levels they date to $7430-7290 \mathrm{cal}$ BP. The new chronology is broadly consistent with previous dating that suggested an antiquity of c. 7010-6400 cal BP based on a conventional date from an adjacent unit (ANU-1373).

Using the new AMS dates, associated artefact classes can be more accurately dated. Three axe roughouts were collected at Manim, from Level 17, Test Unit G and Levels 20 and 23, Test Unit I (Mangi 1984:106; Fig. VIId). Based on the original dating program, the roughout in Test Unit G predates c. 4090-3690 cal BP (ANU-1372) and the deepest in Test Unit I predates 8340-8180 cal BP (Wk-22074) and postdates c. 9300-9090 cal BP (Wk-22075). 
Of the 22 axe flakes collected from Layer V (Mangi's Layers Va and Vb), 14 were derived from Test Unit I (although no specific information is available on their distribution by level). Given that Layer Vb in Test Unit I is represented by Levels 22-24 (Mangi 1984:28), at least some axe flakes predate 8340-8180 cal BP (Wk-22074) and possibly extend as far back as c. 9300-9090 cal BP (Wk-22075).

Additionally, Mangi (1984:108-109, 117) reports on the distribution of grindstones at Manim. All are located within Layer $\mathrm{V}$ : four in Layer $\mathrm{Va}$, nine in Layer $\mathrm{Vb}$, and two in Layer $\mathrm{Vc}$. The dates for Layer $\mathrm{Vb}$ in Test Units $\mathrm{G}$ and I indicate that grindstone technology may date back to over 11 800-10 400 cal BP (ANU-1375). As Mangi (1984:108) speculates, can these grindstones be associated with the production of ground stone axe-adzes? Although grindstones can serve many uses, including processing of plant and animal products, they can also be used to work stone tools. If they were used for stone axe-adze grinding, there is scope for a much greater antiquity for this type of lithic industry in the Upper Waghi Valley region.

A subsidiary question concerns the antiquity of stone exploitation and stone axe manufacture at the Tuman quarries (Burton 1984). The previously reported date of a cutting edge fragment of c. 4090-3690 cal BP (ANU-1372) was derived from Level 19 in Test Unit G, some distance at the site from the find spot in Level 19/2 in Test Unit I. A more closely associated sample of Pandanus from Level 19/6 in Test Unit I returned a more recent calibrated date range of 3370-3220 cal BP (Wk-22071). In part, the discrepancy in ages of c. 700-500 years could be accounted for by an 'old-wood effect' in ANU-1372, although it may in part reflect discrepancies in the antiquity of levels between test units at the site.

\section{A revised occupation chronology for Manim}

The new AMS dating program at Manim, in conjunction with a re-evaluation of previous research on the lithic assemblage, suggests that the main periods of occupation reflected two different cultural orientations. The earlier and main period of occupation started before c. 9300-9090 cal BP (Wk-22075 in Level 24) and lasted until c. 6570-6410 cal BP (Wk-22072 in Level 20). The associated cultural deposit is represented by Levels 20 to 25/26 in Test Unit I, although it is reflected only in Levels 20-23 in Quadrant 6 of Test Unit I. The high rates of lithic deposition of debitage classified by Mangi (1984:Volume 2) as unaltered cores, wasted flakes and 'uncertain' (Figure 6.4), as well as the occurrence of ground stone axe-adzes and axe flakes, are suggestive of on-site stone tool reduction and manufacture. Within this period of occupation, the earliest ground stone axe-adzes conservatively date to 6630-6410 cal BP (Wk-22072, Level 20), although more literally to 7430-7290 cal BP (Wk-22073, Level 21). However, ground stone technology likely predates 9300-9030 cal BP (Wk-22075, Level 24) based on the distribution of axe flakes within Layers $\mathrm{Va}$ and $\mathrm{Vb}$, and possibly earlier if grindstones are considered.

A later period of occupation occurs around c. 3400-3200 cal BP (Wk-22069-20071) and is represented by Levels 17-19. This occupation has much lower rates of lithic deposition and is characterised by the presence of a fragment of a Tuman quarry axe-adze. During this period, people likely visited the site less frequently, may have adventitiously reworked stone artefacts occasionally, but did not engage in more systematic on-site stone tool manufacture. Rather, they obtained axe-adzes through social networks of exchange from specific quarry sites. 


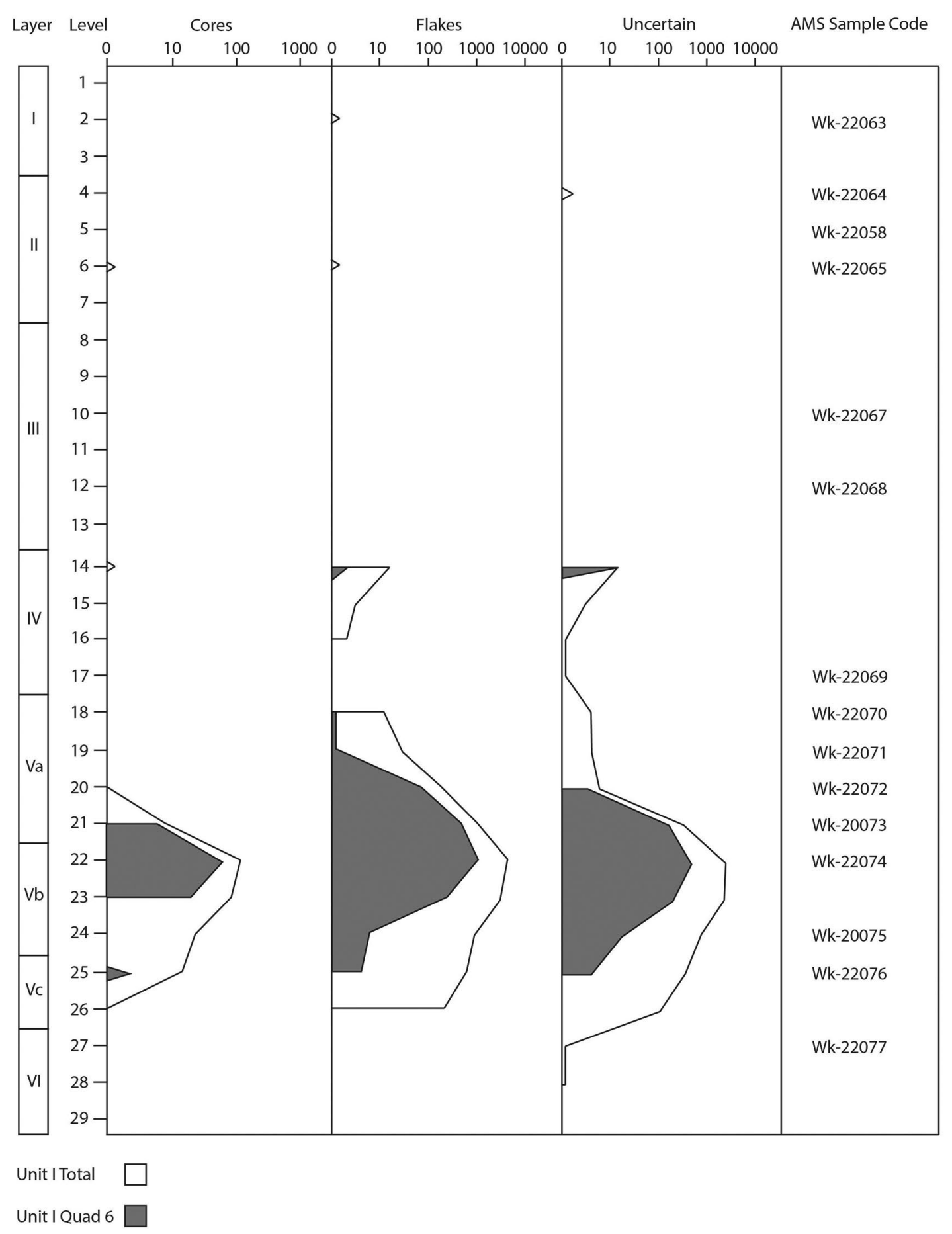

Figure 6.4. Distribution of debitage (comprising cores, flakes and 'uncertain' (as classified by Mangi 1984:vol. 2)) within Test Unit I and Quadrant 6; Test Unit I also depicted.

Note logarithmic scaling of frequencies and AMS sample provenances.

Source: Tim Denham. 


\section{Was there a highland Neolithic?}

In terms of Lubbock's original meaning, the lithic assemblage at Manim does exhibit a Neolithic, namely, the occurrence of ground stone artefacts. Yet, the antiquity of edge ground artefacts on Sahul (the former land mass including Australia and New Guinea) has been claimed to date well into the Pleistocene and is seemingly coeval with initial colonisation of the continent (Geneste et al. 2012; Hiscock et al. 2016). Consequently, the advent of ground stone tools is not a significant technological marker in the region and has little salience for understanding long-term social history on Sahul, even though the Manim assemblage does shed light on the prevalence of ground stone axe-adzes in the Upper Wahgi Valley region.

As applied in Europe, East Asia and South-East Asia (e.g. Bellwood 2005), the Neolithic often encompasses a range of material cultural traits in addition to ground stone axe-adzes, such as agriculture, sedentism, pottery and so on. Consequently, it is necessary to broaden a consideration of the Neolithic to include both diachronic and synchronic lines of evidence that may be relevant to, or have been invoked in, the highlands context. Diachronic interpretations rely on archaeological, geomorphological and palaeoecological lines of evidence to document processes in the past; whereas synchronic interpretations use present-day genetic and linguistic distributions to infer processes in the past.

\section{Diachronic lines of evidence}

Even though the prevalence of ground stone axe-adzes at Manim provides a Neolithic signature of sorts, the significance of this finding to understanding social change, as opposed to agricultural history, is unclear. Ground stone axe-adzes enhanced the ability of people to fell trees. Thereby the technology contributed to the ability of people to disturb and eventually clear montane rainforest on the floor of the Upper Wahgi Valley, which was clearly manifest by 7000-6400 cal BP (Denham and Haberle 2008; Haberle et al. 2012); namely, by the time of the earliest, archaeologically verifiable, cultivation practices on the wetland margin at Kuk Swamp (Denham et al. 2003).

The agricultural chronology at Kuk Swamp, as well as at other wetland sites in the Upper Wahgi Valley and vicinity, indicates the long antiquity of cultivation practices in the highlands (Denham 2018; Golson et al. 2017). Multidisciplinary evidence of environmental manipulation, forest disturbance and plant exploitation dates to c. $10000 \mathrm{cal} \mathrm{BP}$ on the wetland margin at Kuk, with subsequent indirect palaeoecological evidence suggestive of shifting cultivation on the valley floor from then until c. $7000 \mathrm{cal} \mathrm{BP}$. Cultivation using mounds occurs on the wetland margin at Kuk at c. 7000-6400 cal BP, with the digging of ditches to drain cultivated plots occurring from c. $4400-4000 \mathrm{cal} \mathrm{BP.}$

The agricultural chronology at Kuk is practice-focused; namely, it is built upon multidisciplinary evidence of cultivation practices (Denham 2009). Although archaeobotanical and palaeoecological findings indicate the range of plants present, exploited and potentially cultivated at different times, there are no clear morphotypic changes suggestive of domestication for any plant. Indeed, the domestication status of plants under cultivation in New Guinea is not always clear today (Yen 1991) and is not definitive for the determination of agriculture in the Pacific context (following Hather 1996 and Spriggs 1996). Additionally, the primary domestic animals of Pacific agriculture-pig (Sus scrofa) and chicken (Gallus gallus) - were probably introduced to the island of New Guinea within the last 3000 years and only became significant to highlands agriculture much more recently (Sutton et al. 2009). Archaeobotanical and zooarchaeological assemblages from the highlands are not comprehensive or particularly germane to debates concerning the Neolithic. 
In terms of sedentism, house structures have been claimed to date to the Pleistocene at two multi-occupation sites in the highlands-Wañelek (Bulmer 1977b, 1991) and NFX (Watson and Cole 1977). The association between structural elements and radiocarbon dates, as well as the reliability of those dates, at both sites are problematic and should be discounted until more definitive archaeological evidence is forthcoming (Denham 2016; Denham and Ballard 2003). Clearer evidence for early house structures occurs from c. 4500-4000 cal BP in the highlands (Bulmer 1977b, 1991; Watson and Cole 1977); although the archaeology of open settlements may reflect, in large part, sampling biases and site preservation.

Pottery has been reported from c. $3000 \mathrm{cal} \mathrm{BP}$ contexts at two sites in the highlands: Wañelek (Gaffney et al. 2015b) and NFB (Huff 2016). Both claims are likely to be controversial, even though a coastal Lapita site with pottery dating to c. $2800 \mathrm{cal} \mathrm{BP}$ on the south coast of New Guinea is well attested (McNiven et al. 2011). Yet large parts of the highlands were aceramic at contact from the 1930s onwards and were likely always so. Consequently, pottery is marginal to long-term history in the highlands and remained so until the period of European-Australian exploration of the interior during the 20th century.

Putative signatures of the Neolithic occur at vastly different times and have greatly different significance for societies in the highlands of New Guinea. Although agriculture and ground axe-adze technology date to the early to mid-Holocene and become more prevalent from the mid-Holocene onwards, other putative Neolithic signatures are later and less important. Open settlements likely date from c. $4500-4000$ cal BP, while pottery remained marginal after its introduction around c. $3000 \mathrm{cal} \mathrm{BP}$ and domesticated animals, especially pigs, only became central to highlander social life within the last few hundred years.

\section{Synchronic lines of evidence}

The evaluation of synchronic evidence is similarly problematic. Despite recent claims (Bergström et al. 2017), the degrees to which biological, linguistic and genetic markers are consilient and represent the spread of agricultural or Neolithic peoples are unclear. In the New Guinea context, as elsewhere, some conflate the Neolithic with agriculture and make broad generalisations about the past based on contemporary distributions of genes and languages.

For example, an agricultural-based expansion of Proto Trans New Guinea Phylum (pTNG) speakers has been inferred from distributions of major linguistic groups. Even though composition of the Trans New Guinea Phylum is problematic (Foley 2000; Wurm 1992), there is general agreement that approximately several hundred languages in New Guinea are highly related and can be traced to an ancient proto-form (Pawley 2000; Wurm 1975). Pawley proposed that the expansion of pTNG languages across the highlands and into the lowlands was driven by agriculture (Pawley 1998:684). Foley had similarly proposed an agriculture-driven model to account for the recent expansion of three large language groups (Enga, Chimbu, Eastern Highlands; Foley 1992). According to Pawley's model, agricultural groups were able to expand and displace or assimilate non-agricultural groups. Over time, the demic diffusion of agriculturalists was inferred to have occurred at the expense of non-agricultural populations who were marginalised to the least favourable locations, i.e. the lowlands.

Pawley's model appears to fit recent language maps of New Guinea, as well as some recent genetic evidence (Bergström et al. 2017). However, the antiquity, place of origin and dispersal of pTNG, as well as some genetic markers, are currently unknown. Thus, it is not possible to synchronise linguistic and genetic distributions either to the multidisciplinary chronology for the emergence and transformation of agricultural practices (Golson et al. 2017), or to putatively Neolithic cultural traits (such as undertaken for Proto Oceanic and Proto Austronesian; Blust 2009 and Ross 1996, respectively). 


\section{The emergence of agrarian societies}

As Thomas noted (1999), the concept of the Neolithic has come to mean different things to different people who work in different contexts. The term does not constitute a stable or bounded category that has a constant, or universal, application across space and time. If the term is deployed in different ways by different people in different contexts, in what ways is it relevant to the highlands of New Guinea? Perhaps another way to consider the issue is to ask: why invoke the Neolithic? Does usage of the term shed light on the long-term history of the highlands?

The foregoing review of diachronic and synchronic lines of evidence does not reveal a Neolithic horizon for the highlands of New Guinea. Material cultural traits that are often bound up with narratives of the Neolithic occur at markedly different times-such as agriculture, sedentism, pottery and domestic animals - while others are currently absent from the archaeological record-such as mortuary practices. At present, the term Neolithic has no real meaning for the highlands and it makes more sense to shift the debate to the emergence of agrarian societies.

The emergence of agriculture in the highlands of New Guinea does not seem to represent the crossing of a major and irreversible threshold (Denham 2007, 2018). Rather, the conceptual and substantive boundaries between societies reliant on foraging and cultivation are likely to have been porous in the past in New Guinea. Early agriculture is relatively poorly defined in the archaeological record in terms of time, place and practice (Denham 2009). For most societies, cultivation and foraging formed part of the subsistence repertoire up until the recent past; namely, they were complementary rather than alternative strategies (Denham and Haberle 2008). Even though societies in the highlands have come to rely on agriculture for the majority of their food, the historical processes through which this occurred remain to be elicited.

For the New Guinea highlands, the Neolithic is a foreign concept in terms of its origins and application. Instead, the long-term history of the highlands should be considered in terms of the language and literature concerning the emergence of agrarian societies. Although much of the recent focus in the highlands has been on the emergence of early agriculture (Denham et al. 2003), attention needs to refocus on how transformations in agriculture were socially embedded (following Golson 1982; Golson and Gardner 1990; Modjeska 1982). Not only does the adoption of an agricultural innovation - whether new practice, crop or animal—need to make social sense, it also has unforeseen social consequences - whether in terms of demography, commodification of surplus and sexual division of labour. Taken together, agrarian and social changes through time led to the distinctive character of highland societies.

\section{Concluding comments}

Although stone tool assemblages do not generally reflect a clear shift to agrarian practices and lifeways, if they are taken together with wetland archaeological and palaeoecological findings they provide a regional record of human-environment interaction during the early to mid-Holocene (Denham and Haberle 2008; Golson 1982). Currently, the only regional counter-point within the highlands is the dense early to mid-Holocene occupation at Nombe (Denham and Mountain 2016; Evans and Mountain 2005), potentially supplemented by Kiowa (Gaffney et al. 2015a). However, how are these records to be read in terms of the ways people became reliant on the cultivation of food? What did this change mean for their social worlds?

At present, little is known of the emergence of agrarian societies beyond the practices and technologies of cultivation. There is almost no understanding of how the social worlds of communities changed as they reoriented the rhythms of social life around an increasing reliance on cultivated, as opposed to gathered, food. Nonetheless, people in this part of the highlands 
started to become increasingly reliant on cultivated food through the Holocene. The agricultural record of the Upper Wahgi Valley, as well as other valleys in the highlands, needs to be read in terms of this shift to agrarian lifeways without reference to the Neolithic.

\section{Acknowledgements}

The dating research and reanalysis was funded by an Australian Research Council Discovery grant to Denham (DP0666524). The author would like to thank: Jack Golson for permission to undertake research on the Wurup Valley material and paper archive; Nic Dolby and Alice Bedingfield for assistance with selection and identification of plant macroremains for radiocarbon dating; Duncan Wright for assistance with submission of the dates to Waikato for radiocarbon dating; Fiona Petchy for her patience and assistance with the dating of macrobotanical samples at the Radiocarbon Dating Laboratory, University of Waikato; Kay Dancey and Jenny Sheehan for drafting of Figures 6.1-6.4, with assistance of Elle Grono for Fig. 6.4; and John Burton and Rachel Wood for addressing queries. I would like to thank Mathieu Leclerc and James Flexner for the invitation to contribute to this volume and constructive comments on drafts of this paper.

\section{References}

Aplin, K. 1981. 'Kamapuk fauna: A late Holocene vertebrate faunal sequence from the Western Highlands District, Papua New Guinea with implications for palaeoecology and archaeology'. Unpublished BA (Hons) thesis, The Australian National University, Canberra.

Bellwood, P. 2005. First farmers. Oxford: Blackwell.

Bergström, A, SJ Oppenheimer, AJ Mentzer, K Auckland, K Robson, R Attenborough, MP Alpers, G Koki, W Pomat, P Siba, Y Xue, MS Sandhu and C Tyler-Smith. 2017. 'A Neolithic expansion, but strong genetic structure, in the independent history of New Guinea'. Science 6356:1160-1163. doi.org/10.1126/science.aan3842.

Blust, R. 2009. The Austronesian languages. Canberra: Pacific Linguistics.

Bronk Ramsey, C. 2009. 'Bayesian analysis of radiocarbon dates'. Radiocarbon 51:337-360. doi.org/10.1017/S0033822200033865.

Bulmer, S. 1966. 'The prehistory of the Australian New Guinea Highlands: A discussion of archaeological field survey and excavations, 1959-60'. Unpublished MA thesis, University of Auckland, Auckland.

Bulmer, S. 1975. 'Settlement and economy in prehistoric Papua New Guinea: A review of the archaeological evidence'. Journal de la Société des Océanistes 31:7-75. doi.org/10.3406/jso.1975.2688.

Bulmer, S. 1977a. 'Waisted blades and axes'. In Stone tools as cultural markers: Change, evolution and complexity, edited by RVS Wright, 40-59. Canberra: Australian Institute of Aboriginal Studies.

Bulmer, S. 1977b. 'Between the mountain and the plain: Prehistoric settlement and environment in the Kaironk Valley'. In The Melanesian environment, edited by JH Winslow, 61-73. Canberra: Australian National University Press.

Bulmer, S. 1991. 'Variation and change in stone tools in the highlands of Papua New Guinea: The witness of Wanelek'. In Man and a half: Essays in Pacific anthropology and ethnobiology in honour of Ralph Bulmer, edited by A Pawley, 470-478. Auckland: The Polynesian Society. 
Bulmer, S. 2005. 'Reflections in stone: Axes and the beginnings of agriculture in the central highlands of New Guinea'. In Papuan pasts: Cultural, linguistic and biological histories of Papuan-speaking peoples, edited by A Pawley, R Attenborough, J Golson and R Hide, 387-450. Pacific Linguistics 572. Canberra: Pacific Linguistics, Research School of Pacific and Asian Studies, The Australian National University.

Bulmer, S and R Bulmer. 1964. 'The prehistory of the Australian New Guinea Highlands'. American Anthropologist 66 (4, Pt.2):39-76.

Burton, J. 1987 [orig. 1984]. Axe makers of the Wahgi: Pre-colonial industrialists of the Papua New Guinea highlands. Ann Arbor, Michigan: University Microfilms [citations refer to the 1984 thesis].

Childe, VG. 1925. The dawn of European civilisation. London: Kegan Paul.

Christensen, OA. 1975. 'Hunters and horticulturalists: A preliminary report of the 1972-4 excavations in the Manim Valley, Papua New Guinea'. Mankind 10 (1):24-36.

David, B and TP Denham. 2006. 'Unpacking Australian prehistory'. In The social archaeology of Australian Indigenous societies, edited by B David, B Barker and I McNiven, 52-71. Canberra: Aboriginal Studies Press.

Denham, TP. 2003. 'The Kuk morass: Multi-disciplinary investigations of early to mid Holocene plant exploitation at Kuk Swamp, Wahgi Valley, Papua New Guinea'. 2 volumes. Unpublished PhD thesis, The Australian National University, Canberra.

Denham, TP. 2006. 'The origins of agriculture in New Guinea: Evidence, interpretation and reflection'. In Blackwell guide to archaeology in Oceania: Australia and the Pacific Islands, edited by I Lilley, 160-188. Oxford: Blackwell.

Denham, TP. 2007. 'Early to mid-Holocene plant exploitation in New Guinea: Towards a contingent interpretation of agriculture'. In Rethinking agriculture: Archaeological and ethnoarchaeological perspectives, edited by TP Denham, J Iriarte and L Vrydaghs, 78-108. Walnut Creek: Left Coast Press.

Denham, TP. 2009. 'A practice-centred method for charting the emergence and transformation of agriculture'. Current Anthropology 50:661-667. doi.org/10.1086/605469.

Denham, TP. 2016. 'Revisiting the past: Sue Bulmer's contribution to the archaeology of Papua New Guinea'. Archaeology in Oceania 51 (S1):5-10. doi.org/10.1002/arco.5115.

Denham, TP. 2018. Tracing early agriculture in the Highlands of New Guinea: Plot, mound and ditch. Oxford: Routledge. doi.org/10.4324/9781351115308.

Denham, TP and C Ballard. 2003. 'Jack Golson and the investigation of prehistoric agriculture in Highland New Guinea: Recent work and future prospects'. Archaeology in Oceania 38:129-134. doi.org/10.1002/j.1834-4453.2003.tb00539.x.

Denham, TP and SG Haberle. 2008. 'Agricultural emergence and transformation in the Upper Wahgi valley during the Holocene: Theory, method and practice'. The Holocene 18:499-514. doi.org/10.1177/ 0959683607087936.

Denham, TP and MJ Mountain. 2016. 'Resolving some chronological problems at Nombe rock shelter in the highlands of Papua New Guinea'. Archaeology in Oceania 51:73-83. doi.org/10.1002/ arco. 5114 .

Denham, TP, SG Haberle, C Lentfer, R Fullagar, J Field, M Therin, N Porch and B Winsborough. 2003. 'Origins of agriculture at Kuk Swamp in the highlands of New Guinea'. Science 301:189-193. doi.org/ $10.1126 /$ science. 1085255 . 
Donoghue, D. 1988. 'Pandanus and changing site use: A study from Manim Valley, Papua New Guinea'. Unpublished BA (Hons) thesis, University of Queensland, Brisbane.

Donoghue, D. 1989. 'Carbonised plant fossils'. In Plants in Australian archaeology, edited by W Beck, A Clarke and L Head, 90-100. Tempus 1. St Lucia: University of Queensland.

Evans, B and M-J Mountain. 2005. 'Pasin bilong tumbuna: Archaeological evidence for early human activity in the highlands of Papua New Guinea'. In Papuan pasts: Cultural, linguistic and biological histories of Papuan-speaking peoples, edited by A Pawley, R Attenborough, J Golson and R Hide, 363-386. Pacific Linguistics 572. Canberra: Pacific Linguistics, Research School of Pacific and Asian Studies, The Australian National University.

Florin, SA and X Carah. 2018. 'Moving past the "Neolithic problem": The development and interaction of subsistence systems across northern Sahul'. Quaternary International 489:46-62. doi.org/10.1016/ j.quaint.2016.12.033.

Foley, W. 1992. 'Language and identity in Papua New Guinea'. In Human biology in Papua New Guinea: The small cosmos, edited by RD Attenborough and MP Alpers, 136-149. Research Monographs on Human Population Biology no. 10. Oxford: Oxford University Press.

Foley, W. 2000. 'Linguistic prehistory in the Sepik-Ramu Basin'. Talk presented at the Papuan Pasts Conference, Research School of Pacific and Asian Studies, The Australian National University, Canberra.

Gaffney, D, A Ford and GR Summerhayes. 2015a. 'Crossing the Pleistocene-Holocene transition in the New Guinea highlands: Evidence from the lithic assemblage of Kiowa rockshelter'. Journal of Anthropological Archaeology 39:223-246. doi.org/10.1016/j.jaa.2015.04.006.

Gaffney, D, GR Summerhayes, A Ford, J Scott, TP Denham, J Field and WR Dickinson. 2015 b. 'Earliest pottery on New Guinea mainland reveals Austronesian influences in highland environments 3000 years ago'. PLoS ONE 10 (9):e0134497. doi.org/10.1371/journal.pone.0134497.

Garrett, A. 1976. 'Hunters and horticulturalists: Site reports of excavations in the Manim Valley, Papua New Guinea'. Unpublished manuscript on file with author.

Geneste, J-M, B David, H Plisson, J-J Delannoy and F Petchey. 2012. 'The origins of ground-edge axes: New findings from Nawarla Gabarnmang, Arnhem Land (Australia) and global implications for the evolution of fully modern humans'. Cambridge Archaeological Journal 22:1-17. doi.org/10.1017/ S0959774312000017.

Golson, J. 1982. 'The Ipomoean revolution revisited: Society and sweet potato in the upper Wahgi Valley'. In Inequality in New Guinea Highland societies, edited by A Strathern, 109-136. Cambridge: Cambridge University Press.

Golson, J. 2001. 'New Guinea, Australia and the Sahul connection'. In Histories of old ages: Essays in honour of Rhys Jones, edited by A Anderson, I Lilley and S O'Connor, 185-210. Canberra: Pandanus Books, The Australian National University.

Golson, J. 2005. 'The middle reaches of New Guinea history'. In Papuan pasts: Cultural, linguistic and biological histories of Papuan-speaking peoples, edited by A Pawley, R Attenborough, J Golson and R Hide, 451-492. Pacific Linguistics 572. Canberra: Pacific Linguistics, Research School of Pacific and Asian Studies, The Australian National University.

Golson, J and D Gardner. 1990. 'Agriculture and sociopolitical organization in New Guinea Highlands prehistory'. Annual Review of Anthropology 19:395-417. doi.org/10.1146/annurev.an.19.100190. 002143. 
Golson, J, TP Denham, PJ Hughes, P Swadling and J Muke (eds). 2017. Ten thousand years of cultivation at Kuk Swamp in the Highlands of Papua New Guinea. Terra Australis 46. Canberra: ANU Press. doi.org/10.22459/TA46.07.2017.

Haberle, SG, C Lentfer, S O’Donnell and TP Denham. 2012. 'The palaeoenvironments of Kuk Swamp from the beginnings of agriculture in the highlands of Papua New Guinea'. Quaternary International 249:129-139. doi.org/10.1016/j.quaint.2011.07.048.

Hather, JG. 1996. 'The origins of tropical vegeculture: Zingiberaceae, Araceae and Dioscoreaceae in Southeast Asia'. In The origins and spread of agriculture and pastoralism in Eurasia, edited by DR Harris, 538-550. London: University College London Press.

Hiscock, P, S O’Connor, J Balme and T Maloney. 2016. 'World's earliest ground-edge axe production coincides with human colonisation of Australia'. Australian Archaeology 82:2-11. doi.org/10.1080/03 122417.2016.1164379.

Hodder, I. 1990. The domestication of Europe. Oxford: Blackwell.

Huff, J. 2016. 'Revisiting NFB: Ceramic technology in the eastern highlands of Papua New Guinea at 3200 calBP'. Archaeology in Oceania 51 (S1):84-90. doi.org/10.1002/arco.5109.

Lubbock, J. 1865. Pre-historic times. London: Williams and Norgate. doi.org/10.5962/bhl.title.50856.

Mangi, J. 1984. 'Manim 2: 10 years BP: A prehistory of Manim rockshelter, Western Highlands Province, Papua New Guinea'. Unpublished B Litt thesis, 2 vols, The Australian National University, Canberra.

McNiven, IJ, B David, T Richards, K Aplin, B Asmussen, J Mialanes, M Leavesley, P Faulkner and S Ulm. 2011. 'New direction in human colonisation of the Pacific: Lapita settlement of south coast New Guinea'. Australian Archaeology 72:1-6. doi.org/10.1080/03122417.2011.11690525.

Modjeska, CM. 1982. 'Production and inequality: Perspectives from central New Guinea In Inequality in New Guinea Highland societies, edited by A Strathern, 50-108. Cambridge: Cambridge University Press.

Mountain, MJ. 1991. 'Highland New Guinea hunter-gatherers: The evidence of Nombe Rockshelter, Simbu, with emphasis on the Pleistocene'. Unpublished PhD thesis, The Australian National University, Canberra.

Pawley, A. 1998. 'The Trans New Guinea Phylum hypothesis: A reassessment'. In Perspectives on the Bird's Head of Irian Jaya, Indonesia, edited by J Miedema, C Odé and RAC Dam, 665-690. Amsterdam and Atlanta: Editions Rodopi.

Pawley, A. 2000. 'The Trans New Guinea Phylum: Recent research and its implications'. Talk presented at the Papuan Pasts Conference, Research School of Pacific and Asian Studies, The Australian National University, Canberra.

Reimer, PJ, E Bard, A Bayliss, J Beck, PG Blackwell, C Bronk Ramsey, PM Grootes, T Guilderson, H Haflidason, I Hajdas, C Hattž, TJ Heaton, DL Hoffmann, A Hogg, KA Hughen, KF Kaiser, B Kromer, SW Manning, M Niu, RW Reimer, DA Richards, EM Scott, JR Southon, RA Staff, CSM Turney and J van der Plicht. 2013. 'IntCal13 and Marine13 radiocarbon age calibration curves 0-50,000 years cal BP'. Radiocarbon 55:1869-1887. doi.org/10.2458/azu_js_rc.55.16947.

Ross, M. 1996. 'Reconstructing food plant terms and associated terminologies in Proto Oceanic'. In Oceanic studies: Proceedings of the first international conference on Oceanic linguistics, edited by J Lynch and F Pat, 163-221. Pacific Linguistics Series C-133. Canberra: Research School of Pacific and Asian Studies, The Australian National University. 
Spriggs, M. 1996. 'Early agriculture and what went before in Island Melanesia: Continuity or intrusion?' In The origins and spread of agriculture and pastoralism in Eurasia, edited by DR Harris, 524-537. London: University College London Press.

Sutton, A, MJ Mountain, K Aplin, S Bulmer and TP Denham. 2009. 'Archaeozoological records for the highlands of New Guinea: A review of current evidence'. Australian Archaeology 69:41-58. doi.org/ 10.1080/03122417.2009.11681900.

Thomas, J. 1999. Understanding the Neolithic. London: Routledge.

Trigger, B. 2003. A history of archaeological thought. Cambridge: Cambridge University Press.

Watson, VD and JD Cole. 1977. Prehistory of the Eastern Highlands of New Guinea. Seattle: University of Washington Press.

White, JP. 1967. 'Taim bilong bipo: Investigations towards a prehistory of the Papua New Guinea Highlands'. Unpublished PhD thesis, The Australian National University, Canberra.

White, JP. 1972. Ol Tumbuna: Archaeological excavations in the Eastern Central Highlands, Papua New Guinea. Terra Australis 2. Canberra: Department of Prehistory, Research School of Pacific Studies, The Australian National University.

White, JP, KAW Crook and BP Ruxton. 1970. 'Kosipe: A late Pleistocene site in the Papuan Highlands'. Proceedings of the Prehistoric Society 36:152-170. doi.org/10.1017/S0079497X00013128.

Wurm, SA (ed.). 1975. New Guinea area languages and language study. Volume 1: Papuan languages and the New Guinea linguistic scene. Canberra: Department of Linguistics, Research School of Pacific and Asian Studies, The Australian National University.

Wurm, SA. 1992. 'Linguistic prehistory in the New Guinea area'. In Human biology in Papua New Guinea: The small cosmos, RD Attenborough and MP Alpers, 25-35. Research Monographs on Human Population Biology no. 10. Oxford: Oxford University Press.

Yen, DE. 1991. 'Domestication: The lessons from New Guinea'. In Man and a half: Essays in Pacific anthropology and ethnobiology in honour of Ralph Bulmer, edited by A Pawley, 558-569. Auckland: The Polynesian Society. 
This text is taken from Archaeologies of Island Melanesia: Current approaches to landscapes, exchange and practice, edited by Mathieu Leclerc and James Flexner, published 2019 by ANU Press, The Australian National University, Canberra, Australia.

doi.org/10.22459/TA51.2019.06 